\title{
Ewa Kiryluk-Dryjska
}

Poznań University of Life Sciences, Faculty of Economics and Social Sciences

e-mail: kiryluk-dryjska@up.poznan.pl

ORCID: 0000-0003-4353-8196

\section{FORMAL PROCEDURES \\ IN RURAL DEVELOPMENT PLANNING: A COMPARISON OF SELECTED METHODS*}

DOI: $10.15611 / \mathrm{pn} .2020 .4 .06$

JEL Classification: C61, C70

\section{(C) 2020 Ewa Kiryluk-Dryjska}

This is an open access article distributed under the Creative Commons Attribution-NonCommercial-NoDerivs license (http://creativecommons.org/licenses/by-nc-nd/3.0/)

Quote as: Kiryluk-Dryjska, E. (2020). Formal procedures in rural development planning: a comparison of selected methods. Prace Naukowe Uniwersytetu Ekonomicznego we Wrocławiu, 64(4).

\begin{abstract}
The objective of this paper is to compare and discuss the results of the multi-objective linear programming and bankruptcy rules applied to a practical structural policy budget allocation problem using the example of the Polish Rural Development Program 2007-2013. The spread, the Gini indexes and the Lorentz curves were used to compare the funds' dispersion. The results show some similarities between the allocation performed by the linear programming model and the CEL method. Both of the procedures resulted in the allocation concentrated on a limited number of measures, assuring their high financing. Conversely, CEA allocation is the most similar to the actual allocation of the MARD. In both cases the financing is spread among all programs, with a special emphasis on satisfying programs with lower claims. The results demonstrate that, with the use of formal methods, decision-makers can choose if they are willing to set more dispersed or more concentrated budgets.
\end{abstract}

Keywords: fair division, EU funds, rural development, allocation.

* The study was financed from the National Science Center, Poland, grant number: 2017/25/B/ HS4/02513. 


\section{Introduction}

Since Poland's accession to the EU, the total budget (until 2020) of the rural development programs, financed from the second pillar of the Common Agricultural Policy (CAP) ${ }^{1}$ in Poland, exceeded 35 billion Euros. As EU funds have significant potential to positively impact the future structure and competitiveness of agriculture and rural areas, their effective allocation is of crucial importance. However, the multiobjectivity of the programs, the diversity of the proposed measures and the lack of commonly accepted indexes to measure policy effects make the budgeting very complex.

In current economic literature, different forms of formal allocation procedures are proposed to support decision-makers in allocating public budgets. One of them is Multiple Criteria Decision Analysis. It provides insights into the problem structure, explores trade-offs, and provides a set of Pareto-efficient solutions. The concept was introduced by Tinbergen (1952) and further developed by Chiang (1984). The attempts of their practical application in the public sector has been presented by Dyer et al. (1992), Tecle et al. (1998), Bell et al. (2001), Kangas et al. (2001), Bojorquezi et al. (2005), De Agostini (2006) and Stewart et al. (2010), Kim (2008). To support the budgeting of structural policies, Kirschke and Jechlitschka (2003) and Kiryluk-Dryjska (2014) propose multi-objective linear programming.

Another possible way to formally address the political allocation decisions is to apply game theoretic allocation rules ${ }^{2}$. Hougaard (2009) defines an allocation rule as a "general allocation principle that is used with respect to an entire class of similarly structured allocation problems for which there is no objective way to attribute value to specific members"3. There are various types of rules for allocating a common monetary value between individual members of groups. As typically allocation is efficient due to various forms of cooperation with regard to different preferences and strategies of members, often the allocation rules have some game theory basis. Moreover, most of the formal allocation rules presented in the literature are related to the notion of fairness. "Clearly, if the actual allocation is conceived as unfair by some agents in the group, these agents have an incentive to block the cooperation and thereby the group as a whole will suffer an efficiency loss" (Hougaard, 2009).

\footnotetext{
${ }^{1}$ The CAP is composed of two main pillars. The first pillar includes direct payments for farmers and market intervention, while the second pillar comprises rural development policy measures focused on environmental objectives and designed to promote multi-purpose rural development.

${ }^{2}$ The authors used game theory to describe decision-making problem occurring in the second pillar of the CAP. Kiryluk-Dryjska and Bear-Nawrocka (2019) presented how game theory can be used jointly with the partial equilibrium model of the EU agricultural sector to present conflicts regarding the first pillar of the CAP.

${ }^{3}$ Members should be thought of as the broadly defined economic notion of 'an agent', typically from individuals, firms and products to stated objectives.
} 
In the theory of fair allocation, different procedures are proposed for varied types of problems (Young, 1994; Brams and Taylor 1996; Moulin, 2003; Thomson, 2015). Some attempts of their practical application in the public sector for many different decision-making problems were presented by Petrosjan and Zaccour (2003) and Kompas and White (2003). Fragnelli and Kiryluk-Dryjska (2019) demonstrated that formal fair-division allocation rules can also be applied to structural budget allocation.

The objective of this paper is to compare and discuss the results of the two aforementioned allocation procedures: Multiple Criteria Decision Analysis and formal fair division rules applied to a practical structural policy budget allocation problem. More specifically, the authors discussed the results of the multi-objective linear programming model (Kiryluk-Dryjska, 2014) and classical bankruptcy rules (Fragnelli and Kiryluk-Dryjska 2019) using the example of the Polish Rural Development Programme 2007-2013 (PRDP, 2007-2013). The structure of the paper is as follows. The next section presents the basic assumptions of the two approaches, and the following one discusses the properties of the allocations. Finally the paper concludes with a discussion on the possibilities of the practical use of the methods.

\section{Material and methods}

The multi-objective linear programing model presented by Kiryluk-Dryjska (2014) is constructed under the assumption that the PRDP 2007-2013 contributes to three main objectives $\left(\alpha_{1}\right.$ - improving the competitiveness of agriculture and forestry, $\alpha_{2}$-improving the environment and the countryside and $\alpha_{3}$ - improving the quality of life in rural areas), ${ }^{4}$ while maximizing the weighted objective function the model allocates the total budget of the programme $(15723.8 \mathrm{mln}$ euro) among its 18 measures, under given restrictions. The weighted global objective function is defined as:

$$
\max _{x \in X} \sum_{i=1}^{m} \alpha_{i} f_{i}(x)
$$

where: $\alpha_{i}$ - objective weights, $f_{i}(x)$ - objective functions.

Given the three objectives of the program, the model can be presented as follows:

$$
\max _{x \in X} f(x)=\alpha_{1} f_{1}(x)+\alpha_{2} f_{2}(x)+\alpha_{3} f_{3}(x) .
$$

Under the assumption that

$$
\begin{gathered}
\alpha_{1}+\alpha_{2}+\alpha_{3}=1 \\
0 \leq \alpha_{1}, \alpha_{1}, \alpha_{1} \leq 1
\end{gathered}
$$

Following Kirschke and Jechlitschka (2003), the linear objective function of each objective is defined as:

${ }^{4}$ These objectives were officially listed in PRDP 2007-2013. 


$$
f_{i}(x)=\sum_{k=1}^{n} z_{i k} \cdot B_{k},
$$

where: $z_{i k}$-constant marginal and average coefficient of the objective function; $B_{k}-$ budgetary expenses for measures.

The main restrictions of the model consist in a budgetary constraint, and upper and lower allocation boundaries for each of the measures. A budgetary constraint assures that the sum of the budgets for all political programs does not exceed the given value. The upper boundary is the maximum amount of money which can be allocated to a particular measure, whereas lower boundaries assure a minimal level of support for each measure. Moreover, other restrictions were implemented in the model such as, for example, financing rules coming from EU regulations concerning certain programmes, or any national or regional level requirements.

Based on a sensitivity analysis of the weights $\left(\alpha_{1}, \alpha_{2}, \alpha_{3}\right)$ and objective coefficients $z_{i k}$, Kiryluk-Dryjska (2014) presented different allocation results. This paper analysed the results of the so-called 'compromise allocation' for objective weights of $\alpha_{1}=0.2, \alpha_{2},=0.2$ and $\alpha_{3}=0.6$ and objective coefficients $z_{i k}$ calculated based on expert assessments of the measures' effectiveness.

The aim of the bankruptcy rules is to determine the solution of a division problem of a scarce resource, regarding different claims form agents, and respecting the conditions of dividing the whole resource (budget) and of assigning to each claimant a non-negative amount not greater than her/his claim. The analysed the results of three main classical bankruptcy rules: Proportional (PROP), Constrained Equal Awards $(C E A)$ and Constrained Equal Losses $(C E L)$ applied to the division of the PRDP 2007-2013 budget. The calculation formulas adapted by Fragnelli and Kiryluk-Dryjska (2019) are presented below:

Proportional (PROP):

$$
\operatorname{PROP}_{i}(N, c, E)=c_{i} E / C, i \in N
$$

Constrained Equal Awards (CEA):

$$
C E A_{i}(N, c, E)=\min \{c, \alpha\}, i \in N,
$$

where $\alpha$ is a non-negative real number s.t. $\Sigma_{k \in N} C E A_{k}(N, c, E)=E$;

Constrained Equal Losses (CEL):

$$
C E L_{i}(N, c, E)=\max \left\{c_{i}-\beta, 0\right\}, i \in N,
$$

where $\beta$ is a non-negative real number s.t. $\Sigma_{k \in N} C E L_{k}(N, c, E)=E$.

Where $N=\{1, \ldots, n\}$ is the set of claimants; $c=\left(c_{1}, \ldots, c_{n}\right)$ is a positive $n$-dimensional real vector with $c_{i}$ representing the monetary amount of the credit or claim of agent $i \in N ; E$ is a positive real number representing the monetary amount corresponding to the estate to be divided among the claimants, with the condition that $E \leq C=\sum_{k \in N} c_{k}$. 
Applying the bankruptcy rules to the PRDP allocation, Fragnelli and Kiryluk-Dryjska (2019) assumed that political programs represent agents, and the upper bounds of financing of each program constitute the claims. The upper bound (the maximum amount of money which can be allocated to a particular policy programme) was calculated under the assumption that all eligible beneficiaries would apply for a specific programme; the claims are presented in Table 1. In order to compare the results of the procedures, the same values were used as the upper bounds of measures financing in the multi-objective linear programming model. Just as in the former approach, the total budget of PRDP 2007-2013 is allocated among its 18 measures.

Table 1. Claims for bankruptcy rules

\begin{tabular}{|l|c|}
\hline \multicolumn{1}{|c|}{ Political program } & $\begin{array}{c}\text { Claims } \\
\text { (in million Euros) }\end{array}$ \\
\hline Training & 48.0 \\
\hline Young farmers & 520.0 \\
\hline Early retirement & $4,800.0$ \\
\hline Advisory services & 500.0 \\
\hline Modernization & $4,608.0$ \\
\hline Increasing the added value & 1500.0 \\
\hline Infrastructure & 765.0 \\
\hline Food quality schemes & 207.0 \\
\hline Information and publicity & 36.0 \\
\hline Producer groups & 168.0 \\
\hline LFA & $2,448.8$ \\
\hline Agri-environmental & $3,860.0$ \\
\hline Afforestation & 660.0 \\
\hline Forestry production & 140.0 \\
\hline Diversification & 506.9 \\
\hline Micro-enterprises & $2,100.0$ \\
\hline Services for rural population & $4,300.0$ \\
\hline Village renewal & $1,230.0$ \\
\hline Total: & $28,397.1$ \\
\hline
\end{tabular}

Source: (Fragnelli and Kiryluk-Dryjska, 2019).

\section{Results}

Table 2 presents the results of the PRDP 2007-2013 budget calculation with the use of two previously described approaches: the multi-objective linear optimization model and classical bankruptcy rules. Moreover, the results are compared to the 
actual allocation performed by the Ministry of Agricultural and Rural Development (MARD).

Table 2. Allocation of PRDP 2007-2013 with the use of the multi-objective optimization model, classical bankruptcy rules and actual values (in million Euros)

\begin{tabular}{|l|r|r|r|r|r|}
\hline \multicolumn{1}{|c|}{ Program } & Optimisation & \multicolumn{1}{c|}{ Cea } & \multicolumn{1}{c|}{ Cel } & Proporcjonal & Actual \\
\hline Training & 9.6 & 48.0 & 4.8 & 21.8 & 40.0 \\
\hline Young farmer & 103.3 & 520.0 & 52.0 & 236.6 & 420.0 \\
\hline Early retirement & 1880.0 & 2627.2 & 3361.6 & 3031.7 & 2187.6 \\
\hline Advisory services & 100.0 & 500.0 & 50.0 & 227.5 & 350.0 \\
\hline Modernisation & 4608.0 & 1208.0 & 3169.6 & 2096.6 & 1779.9 \\
\hline $\begin{array}{l}\text { Increasing value added of } \\
\text { production }\end{array}$ & 300.0 & 897.2 & 150.0 & 682.5 & 1100.0 \\
\hline Infrastructure & 96.0 & 765.0 & 76.5 & 348.1 & 600.0 \\
\hline Food quality schemes & 40.0 & 207.0 & 20.7 & 94.2 & 100.0 \\
\hline Information and promotion & 7.2 & 36.0 & 3.6 & 16.4 & 30.0 \\
\hline Producer groups & 26.0 & 168.0 & 16.8 & 76.4 & 140.0 \\
\hline LFA & 2449.0 & 2448.8 & 2448.8 & 2448.8 & 2448.8 \\
\hline Agri-environmental programme & 3806.8 & 1987.2 & 2421.6 & 2273.4 & 2303.8 \\
\hline Afforestation & 237.0 & 660.0 & 237.0 & 403.8 & 653.5 \\
\hline Forestry production potential & 28.0 & 140.0 & 14.0 & 63.7 & 140.0 \\
\hline Diversification of activities & 506.9 & 506.9 & 50.7 & 230.6 & 345.6 \\
\hline Microenterprises & 420.0 & 957.2 & 661.6 & 955.5 & 1023.6 \\
\hline Services for rural population & 860.0 & 1177.2 & 2861.6 & 1956.5 & 1471.4 \\
\hline Rural renewal and development & 246.0 & 870.2 & 123.0 & 559.6 & 589.6 \\
\hline Total: & 15723.8 & 15723.8 & 15723.8 & 15723.8 & 15723.8 \\
\hline Max- Min & 4600.8 & 2591.2 & 3358.0 & 3015.3 & 2418.8 \\
\hline Gini index & 0.70 & 0.46 & 0.69 & 0.58 & 0.50 \\
\hline
\end{tabular}

Source: own elaboration based on (Kiryluk-Dryjska, 2014; Fragnelli and Kiryluk-Dryjska, 2019).

Since the optimization model divides the total budget in order to maximize the total objective function its allocation is oriented on measures with high objective coefficients (top experts' evaluations of the programmes' effectiveness). The model allocates the upper bounds of financing for such measures as: modernization of agricultural holdings, diversification into non-agricultural activities and ONW. Agri-environmental programs reach $98 \%$ of the upper bound, cutting the budgets of other projects. The spread between the highest and the lowest financing in this method amounts to $4600 \mathrm{mln}$ euro and is the highest among all analysed methods. 
The CEA algorithm works as follows: first, equal division takes place until each claimant receives an amount equal to the smallest claim. The smallest claimant drops out, and the next increments in the endowment are equally divided among the others until each of them receives an amount equal to the second smallest claim. The second smallest claimant drops out, and so on (Thomson, 2015). As a result in this example, $C E A$ discredits the biggest claimants (the measures with the highest upper bounds). They receive just a part of their claims, while the smaller projects gain the highest possible financing (11 out of the 18 programmes received the upper bounds).

Conversely, applying CEL first, one imposes equal losses on all claimants until their common loss is equal to the smallest claim. The smallest claimant receives 0 , and then drops out. As the endowment continues to decrease, equality of losses is maintained for the others until their common loss is equal to the second smallest claim. The second smallest claimant drops out, and so on. As a result, this procedure penalizes the projects with low claims. Most of the smaller projects (with the lower number of potential beneficiaries or lower unit payment), receive only minimal financing, while larger projects receive higher budgets.

The proportional bankruptcy solution simply distributes the budget in proportion to claims (upper bounds of the programmes). Thus, it is also more beneficial for larger programs than CEA.

When analysing the financing structure as the percentage of the total budget (Figure 1), some similarities may be observed between the optimization model allocation and the CEL method. Both of the procedures result in the allocation concentrated on a limited number of measures assuring their high financing, and largely discrediting the remaining ones. The main difference is however that the optimization model accredits the programmes with top experts' assessments (objective function coefficients), while CEL allocates simply more to the programmes with high upper bounds (claims). For this reason e.g. Early retirement, receives $3361.6 \mathrm{mln}$ euro in CEL, but as it was not highly assessed by the experts, it gets only around half of this amount as a result of the optimization model.

The CEA allocation is the most similar to the actual allocation of MARD. In both cases the financing is distributed among all programmes, with a special emphasis on satisfying programs with lower claims, also the allocation spread of these methods is similar and relatively low (Table 2). This suggests that these methods intend to satisfy many diversified groups of programme's beneficiaries.

The gap between the smallest amount any programme gets and the largest such amount corresponds to the Gini indexes and the Lorenz curves for the analysed allocations (Table 2, Figure 2). It can be observed that all these indicators are the smallest for CEA, and the actual allocation, while the highest is for the optimization model, followed by CEL. The Lorenz curve for CEA is closer to the $45^{\circ}$ line and the Gini coefficients reach lower values compared to all other allocations. However, the actual allocation Gini coefficient (0.5) does not importantly overcome the one for CEA allocation (0.46). 


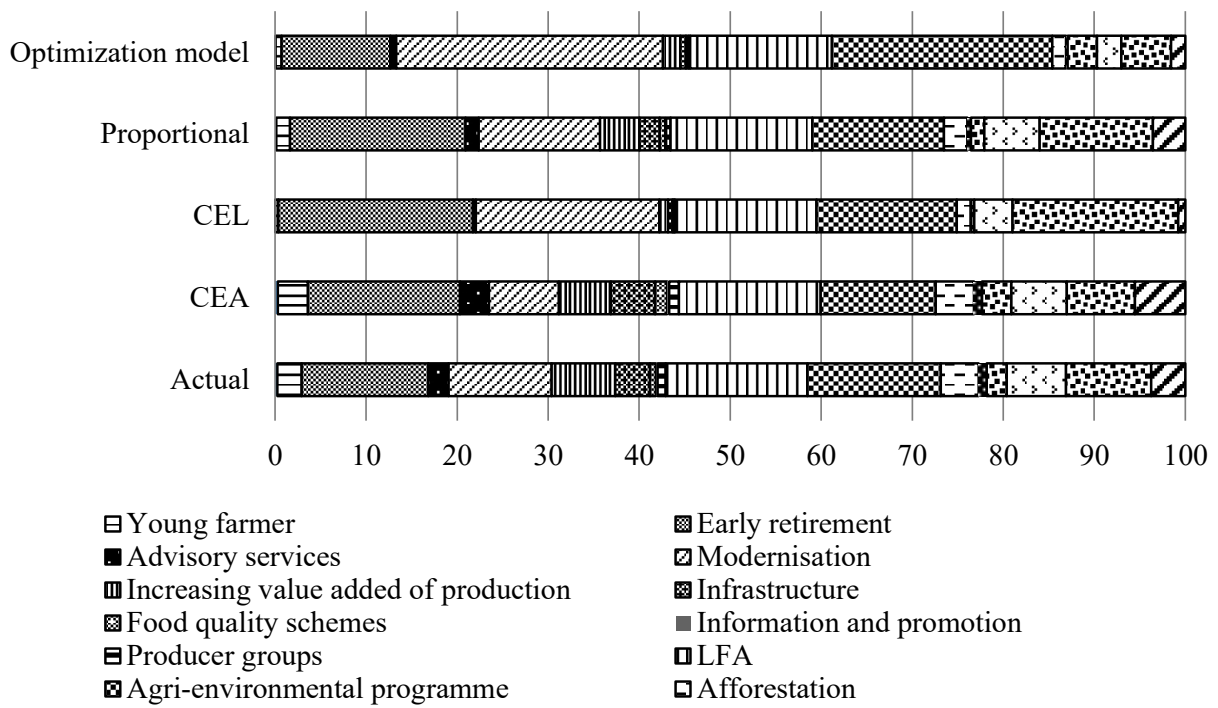

Fig. 1. Allocation of PRDP 2007-2013 with the use of multiobjective optimization model, classical bankruptcy rules and actual values in percentage of the total budget (\%)

Source: own elaboration based on data from Table 1.

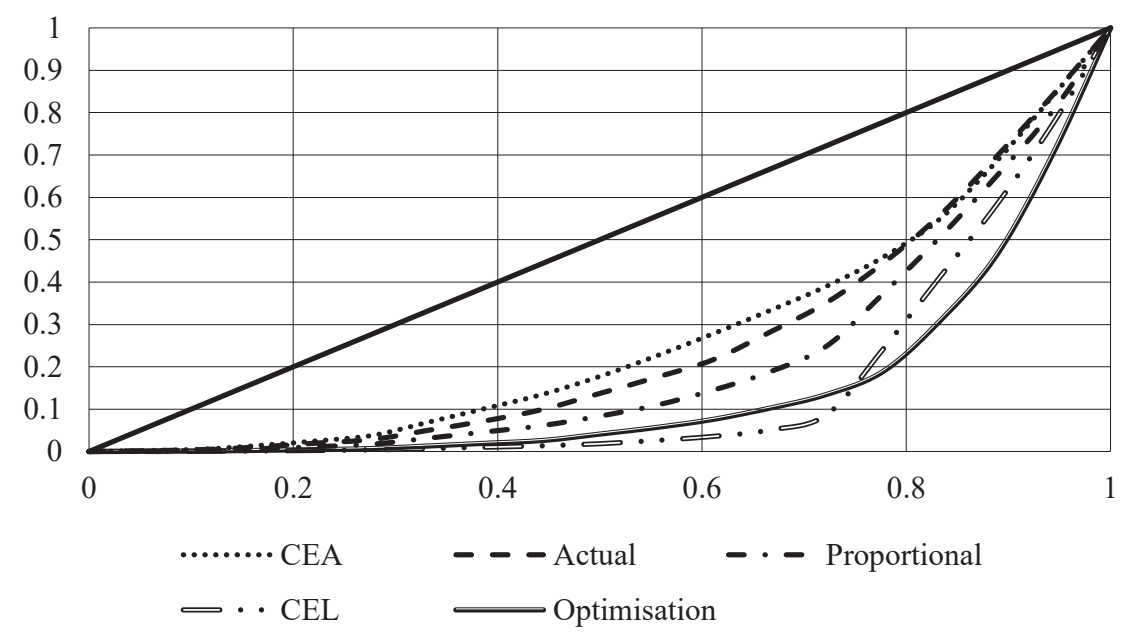

Fig. 2. Lorenz curves based on the data from Table 2

Source: own elaboration based on data from Table 2.

The optimization model allocation is very concentrated on a limited number of projects. The Gini index for the model reaches 0.7 and is the highest among the 
analysed allocations. This demonstrates that the method is very selective and strongly favours the most important programmes. It is worth noting that the Lorenz curves of CEL and the optimization model allocation cross in points $(0.77 ; 1.89)$. Up to the crossing point, the optimization model's Lorenz curve is situated closer to the $45^{\circ}$ line than CEL. Beyond this point CEL allocation is closer to the other approaches. It is interesting that, until the crossing point, in both allocations only smaller projects are financed reaching $13 \%$ and $9 \%$ of the total budget respectively for optimization model for CEL allocation. Thus, up to this point the optimization model provides more egalitarian results compared to CEL. Beyond this point, when the cumulated financing of larger measures is taken into account, the optimization model becomes more selective.

\section{Discussion and conclusions}

All the formal procedures analysed in the paper are feasible and relatively easy to apply. The upper and lower bounds of financing can be objectively calculated based on statistical data. The advantage of the linear programming optimization model is, that apart from these boundaries of financing, it also considers measures' importance. Moreover, it allows to take into account additional constraints such as those coming from EU legislation.

The results of the funds' dispersion show that, in accordance with the general results of Schummer and Thomson (1997), the gap between the smallest amount any programme gets and the largest such amount, in CEA is the smallest among all the bankruptcy rules. It is also smaller compared to the actual allocation and the results of the multi-objective linear programing approach. Hougaard (2009) stated that "CEA is the unique Lorenz-maximizing rationing rule, while CEL is the unique Lorenz-minimizing rationing rule". This has also been confirmed in the real world example of PRDP 2007-2013, and can be used in practice in policy planning. Assuming that the decision-makers wish to assure the most egalitarian distribution of budget among programs, CEA could be used as a method. Conversely, the choice of optimization model and CEL would result in a concentration on measures with higher experts' assessments or claims.

This example shows that the actual allocation of PRDP 2007-2013 performed by the MARD, was similar to CEA. Thus, it was far from being concentrated on the most important programmes.

Moreover, the results clearly demonstrate that, with the use of formal methods, decision-makers can choose if they are willing to set more dispersed or more concentrated budgets. This can depend on the current political situation or the decision-makers' preferences. However, once this important public choice decision is made, the formal allocation rules provide objective results treating all the measures in a fair manner. Therefore decision-makers may not change the given financing of any measures without clearly objective reasons. 
The results of experimental economics (Bolton et al. 2000) reveal that the fairness of the procedures matters for people even more than the fairness of the outcome, i.e. people might be willing to accept an unfair offer if they believe that the offer was the result of implementing a fair policy. This has important implications for policy planning because it shows that the use of formal methods, assuring fairness of allocation, might increase the social acceptance of the policy. This creates a continuing need for possible applications of formal rules in realistic policy-making settings.

\section{References}

Bell, M., Hobbs, B., Elliot, E., Ellis, H., and Robinson, Z. (2001). An evaluation of multicriteria methods in integrated assessment of climate policy. J. Multi-Criteria Decis. Anal., 10, 229-256.

Bojorquezi, L. A., Sanchez-Colon, S., and Martinez, A. F. (2005). Building consensus in environmental impact assessment through multicriteria modeling and sensitivity analysis. Environ. Manage, 36, 469-481.

Bolton, G. E., Brandts, J., and Ockenfels, A. (2000). Fair procedures: evidence from games involving lotteries. Economic Journal, 115, 1054-1076.

Brams, S., and Taylor, A. D. (1996). Fair division. From cake-cutting to dispute resolution. Cambridge, New York, Melbourne: Cambridge University Press.

Chiang, A. C. (1984). Fundamental Methods of Mathematical Economics (third edition). Singapore: Mc-Graw-Hill.

De Agostini, P. (2006). Identifying the best combination of environmental functions using multi-criteria analysis. In J.C. Cooper, F. Perali, M. Veronesi (Eds.), Integrated Assessment and Public Management of Public Resources. Cheltenham, Northampton: Edward Elgar.

Dyer, J. S., Fishburn, P. C., Steuer, R. E., Wallenius, J., and Zionts, S. (1992). Multiple criteria decision making, multi attribute utility theory: the next ten years. Manag. Sci., 38(5), 645-654.

Fragnelli, V., and Kiryluk-Dryjska, E. (2019). Rationing methods for allocating the European Union's Rural Development Funds in Poland, Economia Politica, 36, 295-322,

Hougaard, J. L. (2009). An introduction to allocation rules. Berlin Heidelberg: Springer-Verlag.

Kangas, J., Kangas, A., Leskinen, P., and Pykalainen, J. (2001). MCDA for strategic planning of forestry on state-owned lands in Finland: applications and experiences. J. Multicrit. Decis. Anal., 10, 257-271.

Kim, J. (2000). A model and case for supporting participatory public decision making in democracy. Group Decis. Negotiat., 17, 179-193.

Kirschke, D., and Jechlitschka, K. (2003), Interaktive Programmierungsansätze für die Gestaltung von Agrar- und Umweltprogrammen. Agrarwirtschaft, 52(4).

Kiryluk-Dryjska, E. (2014). Formalizacja decyzji wyboru publicznego. Zastosowanie do alokacji środków strukturalnych Wspólnej Polityki Rolnej UE w Polsce. Warszawa: PWN.

Kiryluk-Dryjska, E., and Baer-Nawrocka, A. (2019). Reforms of the Common Agricultural Policy of the EU - expected results and their social acceptance. Journal of Policy Modeling, 41, 607-622.

Kompas, A., and White, B. (2003). Selecting permit allocation rules for agricultural pollution control: a bargaining solution. Ecological Economics, 47(2-3), 135-147.

Moulin, H. (2003). Fair division and collective welfare. Massachusetts, London, England: The MIT Press Cambridge.

Petrosjan, L., and Zaccour, G. (2003). Time-consistent Shapley value allocation of pollution cost reduction. Journal of Economic Dynamics and Control, 27(3), 381-398. 
Schummer, J., and Thomson, W. (1997).The derivations of the uniform rule. Economics Letters, 55, 333-337.

Stewart, T. J., Joubert, A., and Janssen, R. (2010). MCDA framework for Fishing rights allocation in South Africa. Group Decis. Negotiat., 19, 247-265.

Tecle, A., Bijaya, P., Shrestha, B., and Duckstein, L. (1998). A multi-objective decision support system for multisource Forest management. Group Decis. Negotiat., 7, 23-40.

Thomson, W. (2015), Axiomatic and game-theoretic analysis of bankruptcy and taxation problems: an update. Mathematical Social Sciences, 74, 41-59.

Tinbergen, J. (1952). On the Theory of Economic Policy. Amsterdam: North-Holland Publishing Company.

Young, H. P. (1994). Equity In Theory and Practice. Princeton University Press.

\section{ZASTOSOWANIE FORMALNYCH PROCEDUR W PLANOWANIU ROZWOJU OBSZARÓW WIEJSKICH: PORÓWNANIE WYBRANYCH METOD}

Streszczenie: Celem artykułu jest porównanie i omówienie wyników alokacyjnych dwóch formalnych metod podziału: modelu programowania liniowego oraz metod bankructwa zastosowanych do alokacji budżetu na przykładzie Programu Rozwoju Obszarów Wiejskich w Polsce 2007-2013. W celu porównania rezultatów alokacyjnych omawianych metod wykorzystano indeks Giniego oraz krzywe Lorentza. Wyniki wskazują na pewne podobieństwa między alokacją wykonywaną za pomocą modelu programowania liniowego a metodą bankructwa CEL. Efektem obu procedur jest koncentracja alokacji na ograniczonej liczbie działań zapewniających im wysokie finansowanie. Alokacja w wyniku zastosowania CEA jest najbardziej podobna do rzeczywistej alokacji MRiRW. W obu przypadkach finansowanie jest rozłożone na wszystkie programy, ze szczególnym naciskiem na zaspokojenie programów z niższymi roszczeniami. Wyniki pokazują, że za pomocą formalnych metod decydenci mogą wybierać, czy chcą ustalać bardziej rozproszone, czy bardziej skoncentrowane budżety.

Słowa kluczowe: sprawiedliwy podział, fundusze UE, rozwój obszarów wiejskich, alokacja. 